\title{
Impact of Work Related Factors on Quality of Work Life of Employees in Small Scale Industries in Kanyakumari District
}

\author{
Mrs. R. Sree Devi \& Dr. R. Ganapathi \\ Ph.D. Part-Time Research Scholar, Department of Management Studies, Bharathiar University, Coimbatore. \\ Pin Code - 641046 Tamil Nadu State. \\ Assistant Professor, Directorate of Distance Education, Alagappa University, Karaikudi. Pin Code - 630004. \\ Tamil Nadu State.
}

\begin{abstract}
Quality of Work Life $(Q W L)$ is recognized as the ultimate key to development among all the work systems. The QWL is concerned with improving the employee satisfaction, strengthening the infrastructure at the work place, learning and managing the emerging trends and transitions effectively and efficiently. The exploratory factor analysis shows that healthy and safe working conditions, adequate and fair compensation, growth and development, self improvement and job security and social integration are the factors contributing to the employees' quality of work life in small scale industries. The regression analysis indicates that healthy and safe working conditions, adequate and fair compensation, growth and development, self improvement and job security and social integration are having positive impact on quality of work life in small scale industries. To improve quality of work life is to first identify and then try to satisfy employees' important needs through their experience in their working environment.
\end{abstract}

Key Words: Small-Scale Industries, Exploratory Factor Analysis, Quality of Work Life, Regression.

\section{Introduction}

Quality of Work Life (QWL), a human resource strategy, is recognized as the ultimate key to development among all the work systems. The QWL is concerned with improving the employee satisfaction, strengthening the infrastructure at the work place, learning and managing the emerging trends and transitions effectively and efficiently (Wai and Thomas, 2007). One of the important strategies to improve the QWL is to create work rules that can help in maintaining an orderly atmosphere that is conducive for employees to work in. Work rules can help in improving the quality of work life by means of creating an atmosphere where employees are treated with dignity and respect (Elizur and Shye, 1990). These work rules also help in ensuring the proper conduct of the employees in a professional and secure manner, and encourage them to communicate openly with their employers (Hoque and Rahman, 1999).

QWL consists of opportunities for active involvement in group working arrangements or problem solving that are of mutual benefit to employees or employers, based on labour management cooperation (Evans and Vernon, 2007). People also conceive of QWL as a set of methods, such as autonomous work groups, job enrichment, and high involvement aimed at boosting the satisfaction and productivity of workers (Kumar and Shanubhogue 1996). It requires employee commitment to the organization and an environment in which this commitment can flourish (Lewis, et. al., 2001). Thus, QWL is a comprehensive construct that includes an individual's job related wellbeing and the extent to which work experiences are rewarding, fulfilling and devoid of stress and other negative personal consequences(Rao and Mohan, 2008).

In the small scale industry the employees are the most important resources or assets. They endeavour to provide excellent products, meet and execute customer expectations, achieve competitive advantage and exceptional organizational performance. So, human resources play a pivotal role among the various other resources which are required for ensuring the growth and development of this industry. The availability of skilled managerial and technical manpower in India will contribute considerably to the prosperity of the small scale industry in future. With this backdrop, the present study is attempted to study the impact of work related factors on quality of work life of employees in the small scale industries in Kanyakumari district.

\section{Statement Of Problem}

Quality of Work Life (QWL) is a comprehensive construct that includes an individual's job related wellbeing and the extent to which work experiences are rewarding, fulfilling and devoid of stress and other negative personal consequences. The QWL has been increasing due to several factors. These include increase in education level and consequently job aspirations of employees, association of workers, significance of human resource management, widespread industrial unrest, growing of knowledge in human behaviour and the like. The elements of QWL comprise health and wellbeing, job security, job satisfaction, competence development and the balance between work with non work life. 
A small scale industry contributes greatly to the country's economy. It is one of the major means to overcome unemployment. It leads to improvement in job satisfaction of the employees and contributes to the overall performance of the industries. The absence of QWL leads to the dissatisfaction in job, lack of motivation and moral. The reason to non-performance in small scale industries are many like lack of finance, technology, non availability of skilled labor, turnover, absenteeism and the like but the hidden cause for all these troubles is one and only, "Quality of Work Life".

\section{Objectives Of The Study}

The following are the specific objectives of the study.

1. To identify the factors contributing to the employees' quality of work life in small scale industries.

2. To study the impact of work related factors on quality of work life of employees in small scale industries.

\section{Methodology}

Among the different districts in Tamil Nadu, Kanyakumari district has been purposively selected for the present study. Three hundred employees of small scale industrial units have been selected by adopting random sampling technique through pre-tested and structured questionnaire and the data and information pertain to the year 2013 - 2014. In order to understand the socio-economic profile of employees of small scale industrial units, frequency and percentage analysis are carried out. In order identify the work related factors contributing to the employees' quality of work life in small scale industries, explanatory factor analysis has been employed. In order to examine the impact of work related factors on quality of work life in small scale industries, multiple linear regression has been applied.

\section{Results And Discussion}

\subsection{Socio-Economic Profile of Employees}

The socio-economic profile of the employees of small scale industrial units was analyzed and the results are presented in Table-1. The results show that about 58.67 per cent of employees are males and the rest of 41.33 per cent of them are females. The results indicate that about 44.00 per cent of employees belong to the age group of 31-40 years followed by 21-30 years (38.33 per cent) and 41-50 years (17.67 per cent).

The results reveal that about 44.67 per cent of employees are educated up to secondary level followed by higher secondary (39.33 per cent), diploma ( 11.33 per cent) and under graduation ( 4.67 per cent). It is clear that about 61.67 per cent of employees are married and the rest of 38.33 per cent of them are unmarried. It is observed that about 64.66 per cent of employees are workers followed by supervisors (26.67 per cent) and managers (8.67 per cent).

Table-1. Socio-Economic Profile of the Employees

\begin{tabular}{|l|c|c|}
\hline \multicolumn{1}{|c|}{ Socio-Economic Profile Gender } & Number of Respondents & Percentage \\
\hline \multicolumn{1}{|c|}{ Age Group } & 176 & 58.67 \\
\hline Male & 124 & 41.33 \\
\hline Female & & 38.33 \\
\hline 21 - 30 years & 115 & 44.00 \\
\hline 31 - 40 years & 132 & 17.67 \\
\hline 41 - 50 years & 53 & \\
\hline Educational Qualification & & 44.67 \\
\hline Secondary & 134 & 39.33 \\
\hline Higher Secondary & 118 & 11.33 \\
\hline Diploma & 34 & 4.67 \\
\hline Under Graduation & 14 & \\
\hline Jarital Status & & 61.67 \\
\hline Married Position & 185 & 38.33 \\
\hline Unmarried & 115 & \\
\hline & & \\
\hline Managers & 26 & 26.67 \\
\hline Supervisors & 80 & 64.66 \\
\hline Workers & 194 & \\
\hline
\end{tabular}

\subsection{Factors Contributing to the Employees' Quality of Work Life}

In order to identify the factors contributing to the employees' quality of work life in small scale industries, exploratory factor analysis has been employed. The principal component method of factor analysis was carried out with Eigen values greater than one through varimax rotation and the results obtained through rotated component matrix are presented in Table-2. The results of Kaiser-Meyer-Olkin (KMO Test) measure of 
sampling adequacy $(\mathrm{KMO}=0.542)$ and Bartlett's test of Sphericity $($ Chi-square Value $=0.0011$; Significance $=$ 0.000 ) indicates that the factor analysis method is appropriate.

There are five independent groups which are extracted accounting for a total of 70.12 per cent of variations on 24 variables. Each of the five factors contributes to 19.76 per cent, 16.80 per cent, 13.44 per cent, 10.32 per cent and 9.80 per cent respectively.

Table-2. Factors Contributing to the Employees' Quality of Work Life in Small Scale Industries

\begin{tabular}{|c|c|c|c|c|c|}
\hline Factor & Item & $\begin{array}{c}\text { Rotated } \\
\text { Factor } \\
\text { Loadings }\end{array}$ & $\begin{array}{l}\text { Eigen } \\
\text { Value }\end{array}$ & $\begin{array}{c}\% \text { of } \\
\text { Variation }\end{array}$ & Factor Name \\
\hline \multirow{7}{*}{$\mathbf{I}$} & $\begin{array}{l}\text { I am occupied with my work that I hardly spare } \\
\text { time for my colleagues }\end{array}$ & 0.78 & \multirow{7}{*}{1.98} & \multirow{7}{*}{19.76} & \multirow{7}{*}{$\begin{array}{l}\text { Healthy and Safe Working } \\
\text { Conditions }\end{array}$} \\
\hline & My working conditions have risk of illness & -0.75 & & & \\
\hline & My industrial unit has a healthy environment & 0.76 & & & \\
\hline & $\begin{array}{l}\text { The working condition of my working place is } \\
\text { conducive }\end{array}$ & 0.77 & & & \\
\hline & $\begin{array}{l}\text { The work environment places great emphasis on } \\
\text { safety of individuals }\end{array}$ & -0.65 & & & \\
\hline & It is easy to get materials for efficient working & 0.72 & & & \\
\hline & $\begin{array}{l}\text { Employees are provided with proper working } \\
\text { facilities }\end{array}$ & 0.69 & & & \\
\hline \multirow{5}{*}{ II } & I am getting sufficient income from the work & 0.62 & \multirow{5}{*}{1.62} & \multirow{5}{*}{16.80} & \multirow{5}{*}{$\begin{array}{l}\text { Adequate and Fair } \\
\text { Compensation }\end{array}$} \\
\hline & My financial needs are fulfilled adequately & -0.60 & & & \\
\hline & $\begin{array}{l}\text { I will continue in the present job regardless of } \\
\text { pay }\end{array}$ & 0.65 & & & \\
\hline & I am over compensated in my job & 0.69 & & & \\
\hline & $\begin{array}{l}\text { I feel happy with my chances for salary } \\
\text { increment }\end{array}$ & 0.63 & & & \\
\hline \multirow{4}{*}{ III } & $\begin{array}{l}\text { Work done in improved ways received } \\
\text { recognition }\end{array}$ & -0.73 & \multirow{4}{*}{1.45} & \multirow{4}{*}{13.44} & \multirow{4}{*}{ Growth and Development } \\
\hline & $\begin{array}{l}\text { Opportunities are provided to learn worthwhile } \\
\text { new skill / techniques }\end{array}$ & 0.68 & & & \\
\hline & The use of new technology is encouraged & -0.79 & & & \\
\hline & $\begin{array}{l}\text { The industrial units facilitate the self } \\
\text { improvement of the employees }\end{array}$ & 0.72 & & & \\
\hline \multirow{4}{*}{ IV } & $\begin{array}{l}\text { Employees can get an opportunity to further } \\
\text { develop their skill to do their job through } \\
\text { training }\end{array}$ & 0.70 & \multirow{4}{*}{1.12} & \multirow{4}{*}{10.32} & \multirow{4}{*}{$\begin{array}{c}\text { Self Improvement and Job } \\
\text { Security }\end{array}$} \\
\hline & $\begin{array}{l}\text { The management facilitates career growth and } \\
\text { self improvement of employees }\end{array}$ & 0.60 & & & \\
\hline & $\begin{array}{l}\text { I get opportunities to improve my technical } \\
\text { skills }\end{array}$ & 0.63 & & & \\
\hline & My industrial unit provides job security & 0.71 & & & \\
\hline \multirow{6}{*}{$\mathbf{V}$} & $\begin{array}{l}\text { All the employees of the industrial unit have the } \\
\text { sense of one community }\end{array}$ & 0.62 & \multirow{4}{*}{1.02} & \multirow{4}{*}{9.80} & \multirow{4}{*}{ Social Integration } \\
\hline & $\begin{array}{l}\text { The employees of the industrial unit interact in } \\
\text { terms of ideas and feelings }\end{array}$ & 0.66 & & & \\
\hline & Working in a group is no problem & 0.69 & & & \\
\hline & $\begin{array}{l}\text { The management pays attention to the } \\
\text { grievances of the employees }\end{array}$ & 0.67 & & & \\
\hline & Cumulative $\%$ of Variation & - & - & 70.12 & - \\
\hline & Cronbach's Alpha & - & - & - & 0.82 \\
\hline
\end{tabular}

Extraction Method: Principal Component Analysis.

Rotation Method: Varimax with Kaiser Normalization.

Rotation converged in 10 iterations.

Factor - I: From the results, it is inferred that out of 24 attributes, seven variables have their high, relatively tightly grouped factor loadings on factor - I.

This factor consists of:

- I am occupied with my work that I hardly spare time for my colleagues $(0.78)$

- My working conditions have risk of illness (-0.75)

- My industrial unit has a healthy environment (0.76)

- The working condition of my working place is conducive (0.77)

- The work environment places great emphasis on safety of individuals $(-0.65)$

- It is easy to get materials for efficient working $(0.72)$

- Employees are provided with proper working facilities (0.69) 
Hence, this factor is named as "Healthy and Safe Working Conditions".

Factor - II: is formed with:

- I am getting sufficient income from the work $(0.62)$

- My financial needs are fulfilled adequately $(-0.60)$

- I will continue in the present job regardless of pay $(0.65)$

- I am over compensated in my job (0.69)

- I feel happy with my chances for salary increment $(0.63)$

These variables are named as "Adequate and Fair Compensation"

Factor - III: This factor includes:

- Work done in improved ways received recognition (-0.73)

- Opportunities are provided to learn worthwhile new skill / techniques (0.68)

- The use of new technology is encouraged (-0.79)

- The industrial units facilitate the self improvement of the employees $(0.72)$

These variables are named as "Growth and Development"

Factor - IV: This factor is formed with:

- Employees can get an opportunity to further develop their skill to do their job through training $(0.70)$

- The management facilitates career growth and self improvement of employees $(0.60)$

- I get opportunities to improve my technical skills $(0.63)$

- My industrial unit provides job security (0.71)

This factor is named as "Self Improvement and Job Security"

Factor - V: is formed with:

- All the employees of the industrial unit have the sense of one community (0.62)

- The employees of the industrial unit interact in terms of ideas and feelings (0.66)

- Working in a group is no problem (0.69)

- The management pays attention to the grievances of the employees $(0.67)$

These variables are named as "Social Integration".

Cronbach's Alpha of the scale was 0.82 indicating that each measure demonstrated acceptable internal consistency. It is inferred that healthy and safe working conditions, adequate and fair compensation, growth and development, self improvement and job security and social integration are the factors contributing to the employees' quality of work life in small scale industries.

\subsection{Impact of Work Related Factors on Quality of Work Life of Employees in Small Scale Industries}

In order to study the impact of work related factors on quality of work life of employees in small scale industries, multiple linear regression has been applied and the results are presented in Table- 3. The work related factors extracted through exploratory factor analysis are considered as independent variables and the quality of work life is considered as dependent variable.

Table-3. Impact of Work Related Factors on Quality of Work Life of Employees in Small Scale Industries

\begin{tabular}{|c|c|c|c|}
\hline Work Related Factors & $\begin{array}{c}\text { Regression } \\
\text { Co-efficients }\end{array}$ & t - Value & Sig. \\
\hline Intercept & $1.130^{* *}$ & 3.562 & .000 \\
\hline Healthy and Safe Working Conditions $\left(\mathrm{X}_{1}\right)$ & $.446^{* *}$ & 3.754 & .000 \\
\hline Adequate and Fair Compensation $\left(\mathrm{X}_{2}\right)$ & $.462^{* *}$ & 3.810 & .010 \\
\hline Growth and Development $\left(\mathrm{X}_{3}\right)$ & $.438^{* *}$ & 3.762 & .010 \\
\hline Self Improvement and Job Security $\left(\mathrm{X}_{4}\right)$ & $.424^{* *}$ & 3.818 & .000 \\
\hline Social Integration $\left(\mathrm{X}_{5}\right)$ & $.422^{* *}$ & 3.746 & .010 \\
\hline 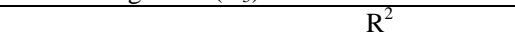 & 0.69 & - & - \\
\hline Adjusted $\mathrm{R}^{2}$ & 0.67 & - & - \\
\hline $\mathrm{F}$ & 9.764 & - & 0.00 \\
\hline $\mathrm{N}$ & 300 & - & - \\
\hline
\end{tabular}

Note: ${ }^{* *}$ Significance at one per cent level 
The results indicate that the coefficient of multiple determination $\left(R^{2}\right)$ is 0.69 and adjusted $R^{2}$ is 0.67 indicating the regression model is good fit. It is inferred that about 67.00 per cent of the variation in dependent variable (Quality of Work Life) is explained by the independent variables (Work Related Factors). The F-value of 9.764 is statistically significant at one per cent level indicating that the model is good fit.

The results show that healthy and safe working conditions, adequate and fair compensation, growth and development, self improvement and job security and social integration are having positive impact on quality of work life in small scale industries at one per cent level of significance. Therefore, the null hypothesis of there is no significant impact of work related factors on quality of work life is rejected.

\section{Conclusion}

The present study reveals that majority of employees of small scale industries are males and most of them belong to the age group of 31-40 years. Majority of them are educated up to secondary level and majority of them are married and most of them are workers. The exploratory factor analysis shows that healthy and safe working conditions, adequate and fair compensation, growth and development, self improvement and job security and social integration are the factors contributing to the employees' quality of work life in small scale industries. The regression analysis indicates that healthy and safe working conditions, adequate and fair compensation, growth and development, self improvement and job security and social integration are having positive impact on quality of work life in small scale industries.

To improve quality of work life is first to identify and then try to satisfy employee's important needs through their experience in their working environment. Since the healthy and safe working environment is important for employees to work efficiently, the small scale industries should provide good and safe working conditions for employees and proved the necessary working facilities to them.

The small scale industrial units must ensure that employees are getting sufficient income and increment should be paid based on the performance of the employees and it will motivate them to perform well. The small scale industrial unit should provide opportunity to employees for learning new techniques and also for knowledge development. Besides, employees should be encouraged to adopt modern and innovative methods to enhance the productivity. The small scale industrial units allow employees to interact in terms of ideas and feelings with others and management should pay attention to the grievances of the employees in order to create a smooth and conducive climate to increase the work efficiency.

\section{References}

[1] Chan, Ka Wai and A. Wyatt, Thomas, Quality of work life: a study of employees in Shanghai, China, Asia Pacific Business Review, 13 (4), 2007, 501-517.

[2] D. Elizur and S. Shye, Quality of work life and its relation to quality of life, Applied Psychology, 39 (3), 1990, 275-291.

[3] M.E. Hoque and A. Rahman, Quality of working life \& job behaviour of workers in Bangladesh: a comparative study of private and public sectors, Indian Journal of Industrial Relations, 35 (2), 1999, 175-184.

[4] A. Evans and K. Vernon, Work-life balance in Hong Kong: case studies, Community Business, June 2007, 12-14.

[5] H. Kumar and A. Shanubhogue, Quality of work life-an empirical approach, Manpower Journal, 32 (3), 1996, 17-32.

[6] D. Lewis, K. Brazil, P. Krueger, L. Lohfeld and E. Tjam, Extrinsic and intrinsic determinants of quality of work life, Leadership in Health Service, 14 (2), 2001, 9-15.

[7] P.K. Rao and A.C. Mohan, Perceptual factors in quality of work life of Indian employees, Management and Labour Studies, 33 (3), 2008, 373-383. 